\title{
Characterization of Thermal and Physical properties of Biofield Treated Acrylamide and 2-Chloroacetamide
}

\author{
Mahendra $\mathrm{KT}^{1}$, Shrikant $\mathbf{P}^{1}$, Rakesh $\mathrm{KM}^{1}$, and Snehasis $\mathbf{J}^{2^{\star}}$ \\ ${ }^{1}$ Trivedi Global Inc., 10624 S Eastern Avenue Suite A-969, Henderson, NV 89052, USA \\ ${ }^{2}$ Trivedi Science Research Laboratory Pvt. Ltd., Hall-A, Chinar Mega Mall, Chinar Fortune City, Hoshangabad Rd., Bhopal- 462026, Madhya Pradesh, India
}

\begin{abstract}
Acrylamide (AM) and 2-chloroacetamide (CA) are widely used in diverse applications such as biomedical, drug delivery, waste water treatment, and heavy metal ion removal. The objective of this study was to evaluate the influence of biofield treatment on physical and thermal properties of amide group containing compounds (AM and CA). The study was performed in two groups (control and treated). The control group remained as untreated, and biofield treatment was given to treated group. The control and treated compounds were characterized by X-ray diffraction (XRD), differential scanning calorimetry (DSC), thermogravimetric analysis (TGA) and surface area analysis. XRD of treated AM showed decrease in intensity of peaks as compared to control sample. However, the treated AM showed increase in volume of unit cell $(0.16 \%)$ and molecular weight $(0.16 \%)$ as compared to control. The crystallite size was decreased by $33.34 \%$ in treated AM as compared to control Whereas, the XRD diffractogram of treated CA showed increase in intensity of crystalline peaks as compared to control. The percentage volume of unit cell $(-1.92 \%)$ and molecular weight $(-1.92 \%)$ of treated CA were decreased as compared to control. However, significant increase in crystallite size (129.79\%) was observed in treated CA as compared to control. DSC of treated AM showed increase in melting temperature as compared to control sample. Similarly, the treated CA also showed increase in melting temperature with respect to control. Latent heat of fusion $(\Delta \mathrm{H})$ was significantly changed in treated $A M$ and CA as compared to control samples. TGA showed increase in thermal stability of treated $A M$ and CA which was evidenced by increase in thermal decomposition temperature $\left(T_{\max }\right)$ as compared to control. Surface area analysis of treated AM showed increase $(31.6 \%)$ in surface area as compared to control. However, a decrease (30.9\%) in surface area was noticed in treated CA as compared to control. Study results suggest that biofield treatment has significant impact on the physical and thermal properties of $\mathrm{AM}$ and $\mathrm{CA}$.
\end{abstract}

Keywords: Acrylamide; 2-chloroacetamide; Biofield treatment; X-ray diffraction; Differential scanning calorimetry; Thermogravimetric analysis; Surface area analysis

Abbreviation: XRD: X-Ray Diffraction; DSC: Differential Scanning Calorimetry; TGA: Thermogravimetric Analysis; AM: Acrylamide; CA: 2-Chloroacetamide

\section{Introduction}

Acrylamide (AM) is a monomer used for synthesis of polyacrylamide that is commonly utilized for biomedical, pharmaceutical and wastewater treatment applications. AM based polymer was introduced as a support matrix for electrophoresis in 1959 [1]. Generally, the AM based gels are produced using bifunctional cross linker such as $\mathrm{N}$-methylene bisacrylamide [2]. AM based polymers are widely used in areas such as enzyme immobilization [3,4], carrier for delivery of drugs and bioactive compounds [5-9], stimuli responsive materials [10,11] and in non-absorbable soft tissue fillers used for body contouring in reconstructive surgery [12]. On the other hand 2-chloroacetamide (CA) is a chlorinated organic compound used as herbicide and preservative [13]. The amide group of CA has better selectivity towards mercury binding, hence it has been commonly used for heavy metal ion removal applications [14]. The structural and conformational nature of CA have been previously studied by many researchers $[15,16]$. However, the AM and CA have toxicity problems which need to be addressed in order to make it useful for other areas such as biomedical and novel drug development. Biofield treatment has been recently used as a strategy for changing the atomic and physical properties of various materials [17-20].

Bioelectrography dates back to 1770 when German scientist George Christopher Lichtenberg observed light coming out from subjects in electrical fields [21]. Researchers have showed that short lived electrical events or action potential exist in several type of mammalian cells such as neurons, muscle cells, and endocrine cells [22]. For instance the cells present in central nervous system of human body communicate with each another by means of electrical signals that travel along the nerve processes. Therefore, it was hypothesized that biofield exists around the human body and the evidence was found using Electromyography, Electrocardiography and electroencephalogram [23]. Human has the ability to harness the energy from environment or universe and can transmit into any living or nonliving object around the Globe. The object(s) always receive the energy and responds in a useful way that is called biofield energy and the process is known as biofield treatment. Mr. Mahendra K. Trivedi is known to transform the characteristics of various living and non-living things using his biofield treatment. The biofield treatment had significantly improved the production and quality of various agricultural products [24-27]. Biofield treatment has shown excellent results in improving antimicrobial susceptibility, and alteration of biochemical reactions, as well as induced alterations in characteristics of pathogenic microbes [28-30]. The biofield treatment had also caused an increase in growth and anatomical characteristics

*Corresponding author: Snehasis J, Trivedi Science Research Laboratory Pvt. Ltd., Hall-A, Chinar Mega Mall, Chinar Fortune City, Hoshangabad Rd., Bhopal- 462026 Madhya Pradesh, India, Tel: 917556660006; E-mail: publication@trivedisrl.com

Received: July 06, 2015; Accepted: July 22, 2015; Published: July 29, 2015

Citation: Mahendra KT, Shrikant P, Rakesh KM, Snehasis J (2015) Characterization of Thermal and Physical properties of Biofield Treated Acrylamide and 2-Chloroacetamide. Organic Chem Curr Res 4: 143. doi:10.4172/2161 0401.1000143

Copyright: (c) 2015 Mahendra KT, et al. This is an open-access article distributed under the terms of the Creative Commons Attribution License, which permits unrestricted use, distribution, and reproduction in any medium, provided the original author and source are credited. 
of an herb Pogostemon cablin that is commonly used in perfumes, in incense/insect repellents, and alternative medicine [31]. By conceiving the above research outcome of biofield treatment, an attempt was made here to study the influence of biofield on physical and thermal properties of AM and CA.

\section{Materials and Methods}

Acrylamide (AM) and 2-chloroacetamide (CA) were procured from S D Fine Chemicals Pvt., Ltd., India. Each sample was divided into two parts; one was kept as a control, while other was subjected to Mr. Trivedi's biofield treatment and coded as treated sample. The treatment group in sealed pack was handed over to Mr. Trivedi for biofield treatment under standard laboratory condition. Mr. Trivedi provided the treatment through his energy transmission process to the treated group without touching the sample. The biofield treated samples were returned in the similar sealed condition for characterization using $\mathrm{XRD}, \mathrm{DSC}, \mathrm{TGA}$ and surface area analysis techniques.

\section{Characterization}

X-ray diffraction (XRD) study: XRD analysis was carried out on Phillips, Holland PW 1710 X-ray diffractometer system, which had a copper anode with nickel filter. The radiation of wavelength used by the XRD system was $1.54056 \AA$. The data obtained from this XRD were in the form of a chart of $2 \theta$ vs. intensity and a detailed table containing peak intensity counts, $d$ value $(\AA)$, peak width $\left(\theta^{\circ}\right)$, relative intensity (\%) etc. Additionally, PowderX software was used to calculate unit cell volume.

The crystallite size $(\mathrm{G})$ was calculated by using formula:

$$
\mathrm{G}=\mathrm{k} \lambda /(\mathrm{b} \operatorname{Cos} \theta)
$$

Here, $\lambda$ is the wavelength of radiation used and $\mathrm{k}$ is the equipment constant $(=0.94)$. However, the percentage change in all parameters such as, unit cell volume and percent change in crystallite size was calculated using the following equation:

Percent change in unit cell volume $=\left[\left(\mathrm{V}_{\mathrm{t}}-\mathrm{V}_{\mathrm{c}}\right) / \mathrm{V}_{\mathrm{c}}\right] \times 100$

Where, $\mathrm{V}_{\mathrm{c}}$ and $\mathrm{V}_{\mathrm{t}}$ are the unit cell volume of control and treated powder samples respectively

Percent change in crystallite size $=\left[\left(G_{t}-G_{c}\right) / G_{c}\right] \times 100$

Where, $G_{c}$ and $G_{t}$ are crystallite size of control and treated powder samples respectively.

The molecular weight of atom was calculated using following equation:

Molecular weight $=$ number of protons $\times$ weight of a proton + number of neutrons $\mathrm{x}$ weight of a neutron + number of electrons $\mathrm{x}$ weight of an electron.

Molecular weight in $\mathrm{g} / \mathrm{Mol}$ was calculated from the weights of all atoms in a molecule multiplied by the Avogadro number $\left(6.023 \times 10^{23}\right)$. The percent change in molecular weight was calculated using the following equation:

Percent change in molecular weight $=\left[\left(M_{t}-M_{c}\right) / M_{c}\right] \times 100$

Where, $M_{c}$ and $M_{t}$ are molecular weight of control and treated powder sample respectively.

Differential scanning calorimetry (DSC) study: The control and treated samples (AM and CA) were analyzed by using a Pyris-6 Perkin
Elmer DSC on a heating rate of $10^{\circ} \mathrm{C} / \mathrm{min}$ under air atmosphere and air was flushed at flow rate of $5 \mathrm{~mL} / \mathrm{min}$.

Thermogravimetric analysis-differential thermal analysis (TGADTA): Thermal stability of control and treated samples (AM and CA) were analyzed by using Metller Toledo simultaneous TGA and Differential thermal analyzer (DTA). The samples were heated from room temperature to $400^{\circ} \mathrm{C}$ with a heating rate of $5^{\circ} \mathrm{C} / \mathrm{min}$ under air atmosphere.

Surface area analysis: Surface area of AM and CA were characterized by surface area analyzer, SMART SORB 90 BET using ASTM D 5604 method which had a detection range of $0.2-1000 \mathrm{~m}^{2} / \mathrm{g}$.

\section{Results and Discussion}

\section{$\mathrm{X}$-ray diffraction}

X-ray diffraction study was conducted to study the crystalline nature of the control and treated AM. XRD diffractogram of control AM showed (Figure 1) intense crystalline peaks at $2 \theta$ equals to $11.90^{\circ}$, $19.34^{\circ}, 19.55^{\circ}, 24.00^{\circ}, 24.51^{\circ}, 28.27^{\circ}, 28.53^{\circ}, 36.38^{\circ}$ and $49.21^{\circ}$. These peaks showed the crystalline nature of AM. Whereas, the treated AM showed decreased intensity of the XRD peaks. The XRD diffractogram showed crystalline peaks at $2 \theta$ equals to $11.75^{\circ}, 11.99^{\circ}, 19.17^{\circ}, 19.32^{\circ}, 23.69^{\circ}$, $23.97^{\circ}, 24.14^{\circ}, 28.50^{\circ}$ and $36.05^{\circ}$. The decrease in intensity of crystalline planes after biofield treatment of AM may be due to disturbed regular pattern of the atoms. The volume of unit cell, crystallite size and change in molecular weight were computed from the XRD diffractogram using Powder X software. The results are presented in Figure 2. An increase $(0.16 \%)$ in volume of unit cell was observed in treated AM as compared to control. The treated AM showed $0.16 \%$ increase in molecular weight as compared to control. It is hypothesized that biofield energy possibly acted on treated AM crystals at nuclear level and altered the number of proton and neutrons as compared to control, which may led to increase the molecular weight. The treated AM $(46.20 \mathrm{~nm})$ showed (Table 1) decrease in crystallite size as compared to control (69.31 $\mathrm{nm}$ ) and percentage decrease in crystallite size was $33.34 \%$ (Figure 3 ). The existence of severe lattice strains was evidenced by the change in unit cell volume. Thus, it is assumed that presence of these internal strains might be a reason for fracturing the grains into sub grains which leads to decrease in crystallite size of treated sample. The XRD diffractogram of control and treated CA are presented in Figure 4. The XRD diffractogram of control CA showed occurrence of intense crystalline peaks at $2 \theta$ equals to $26.87^{\circ}, 33.09^{\circ}, 35.32^{\circ}$ and $35.45^{\circ}$. This clearly showed the crystalline nature of the control sample. However, the treated CA showed the increase in intensity of the XRD peaks. The treated sample showed (Figure 4) XRD peaks at $17.64^{\circ}, 27.09^{\circ}, 33.24^{\circ}$,

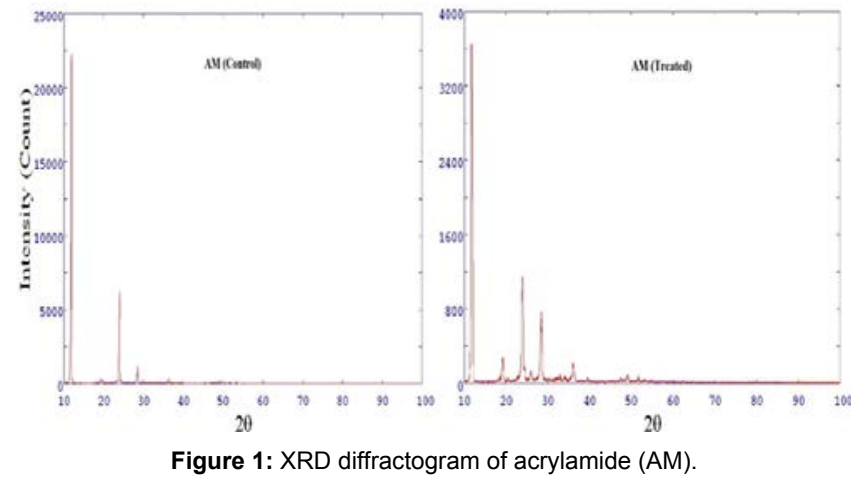

Figure 1: XRD diffractogram of acrylamide (AM). 
$35.52^{\circ}, 35.63^{\circ}$ and $44.78^{\circ}$. The significant increase in intensity of the XRD peaks revealed the enhanced crystalline nature of the sample. It is presumed that biofield energy may be absorbed by the CA crystals, which led to formation of more symmetrical crystalline long-range pattern; that caused increase in crystallinity. The volume of unit cell of treated CA was decreased with respect to control sample and the percentage decrease in volume of unit cell was $-1.92 \%$. The molecular weight of treated CA was reduced by $1.92 \%$ as compared to control and this may be due to decrease in number of protons and neutrons after biofield treatment (Figure 2). However, the treated CA showed (Table 1) a significant increase in crystallite size $(108.60 \mathrm{~nm})$ as compared to control CA $(47.26 \mathrm{~nm})$. The percentage change in crystallite size was $129.79 \%$. This showed (Figure 3) the significant impact of biofield treatment on increasing the crystallite size of treated CA with respect to control. It was previously reported that crystallite size increases with elevation in temperature or thermal energy. Hence, it is assumed that biofield energy may reduce the thermodynamically driving force which automatically causes decrease in nucleus densities and raises the crystallite size $[32,33]$.

\section{DSC studies}

The DSC thermogram of control and treated AM are shown in Figure 5. The DSC thermogram of control AM showed the presence of sharp endothermic peak at $86^{\circ} \mathrm{C}$ which was due to melting temperature of the control. However, the treated AM showed (Figure 5) an increase in melting temperature peak $\left(88^{\circ} \mathrm{C}\right)$ as compared to control. It indicated that biofield treated AM had better thermal stability as compared to control. DSC thermogram of control and treated CA are depicted in Figure 6. The DSC graph of the control sample showed sharp endothermic inflexion at $114^{\circ} \mathrm{C}$ which was responsible for melting of the compound. DSC thermogram of control CA showed another two endothermic peaks at $135^{\circ} \mathrm{C}$ and $168^{\circ} \mathrm{C}$. Katayama performed X-ray investigation on CA and found that there are two forms of compound in crystalline state, one being more stable than other [34]. Hence, it is presumed that two endothermic peaks in control CA may be represented to two crystalline polymorphs present in the compound. Whereas, the treated CA showed (Figure 6) an increase in melting temperature and it was observed at $116^{\circ} \mathrm{C}$. It confirmed that biofield treatment may induced regular pattern in the CA atoms and hence increase in thermal stability. It was reported that $\gamma$ radiation treatment increased the thermal stability of poly (3-hexadecythiophene). Therefore, it is presumed that biofield treatment may cause conformational changes and crosslinking in AM and CA compounds which led to increase in thermal stability [35]. Latent heat of fusion $(\Delta \mathrm{H})$ was calculated from the DSC data and results are depicted in Table 2. The control AM showed a $\Delta H$ of $231.96 \mathrm{~J} / \mathrm{g}$ and it was decreased to $156.83 \mathrm{~J} / \mathrm{g}$ in treated

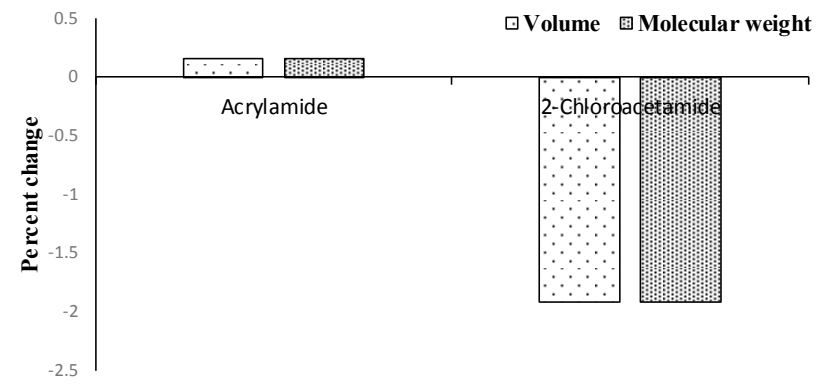

Figure 2: Percent change in volume of unit cell $\left(10^{-23} \mathrm{~cm}^{3}\right)$ and molecular weight of treated acrylamide (AM) and 2-chloroacetamide (CA).

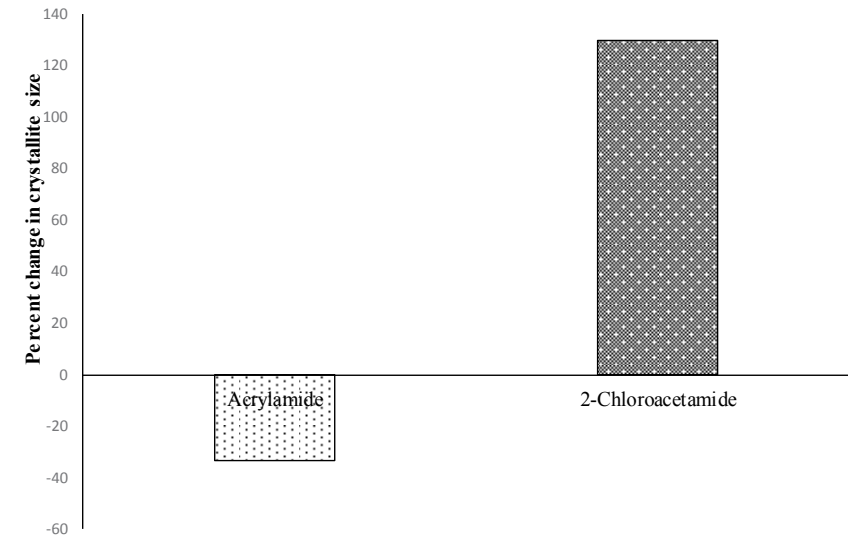

Figure 3: Percent change in crystallite size (' $G$ ' $\times 10^{-9} \mathrm{~nm}$ ) of treated acrylamide (AM) and 2-chloroacetamide (CA)

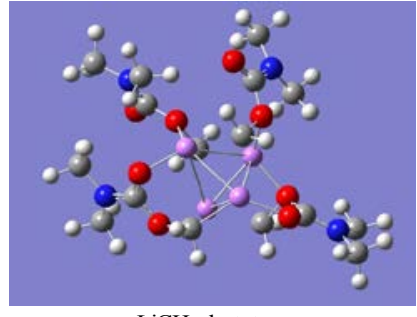

$\mathrm{LiCH}_{2} \mathrm{cb}$ tetramer

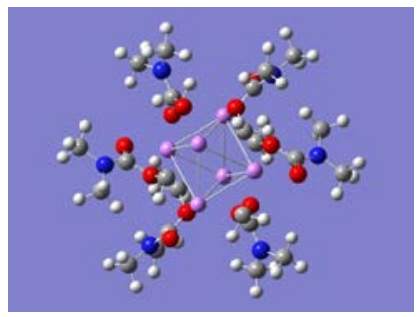

$\mathrm{LiCH}_{2} \mathrm{cb}$ hexamer
Figure 4: XRD diffractogram of 2-chloroacetamide (CA).
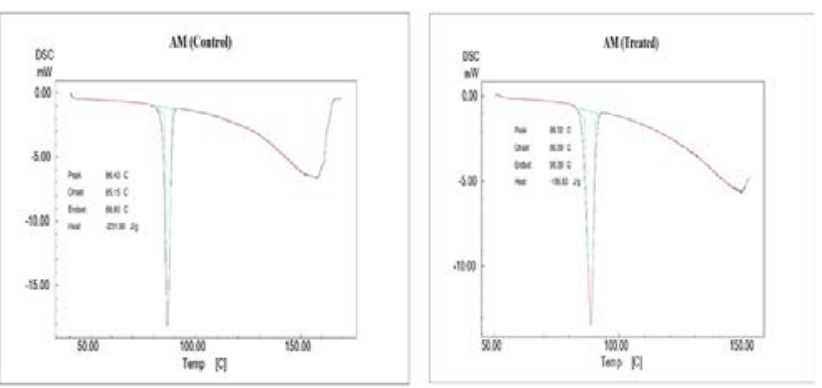

Figure 5: DSC thermogram of acrylamide (AM).

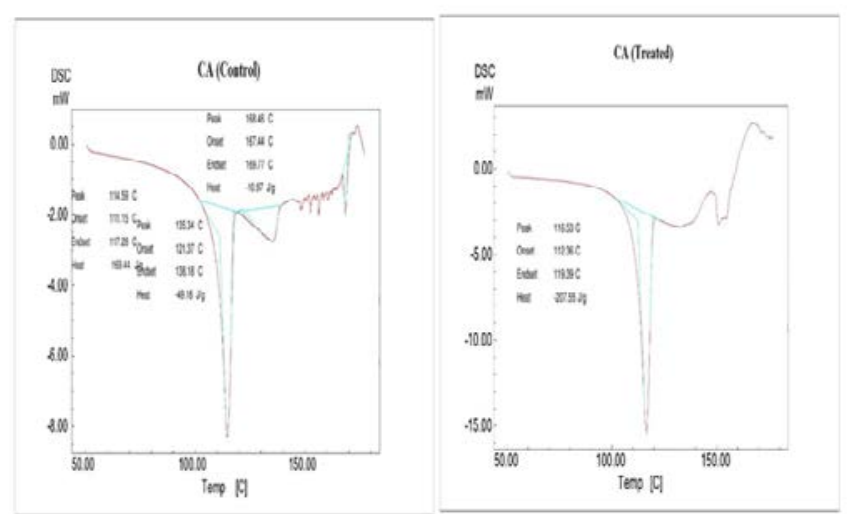

Figure 6: DSC thermogram of 2-chloroacetamide (CA). 


\begin{tabular}{|c|c|c|c|}
\hline Compound Characteristics & Sample type & Acrylamide & 2-Chloroacetamide \\
\hline \multirow{2}{*}{ Volume of unit cell $\left(10^{-23} \mathrm{~cm}^{3}\right)$} & Control & 423.4 & 392.13 \\
\cline { 2 - 4 } & Treated & 424.09 & 384.61 \\
\hline \multirow{2}{*}{ Crystallite Size 'G' $\times 10^{-9} \mathrm{~m}$} & Control & 69.31 & 47.26 \\
\cline { 2 - 4 } & Treated & 46.20 & 108.60 \\
\hline \multirow{2}{*}{ Molecular Weight $(\mathrm{g} / \mathrm{mol})$} & Control & 72.93 & 94.77 \\
\cline { 2 - 4 } & Treated & 73.05 & 92.95 \\
\hline
\end{tabular}

Table 1: XRD data (volume of unit cell, crystallite size and molecular weight) of acrylamide (AM) and 2-chloroacetamide (CA).

\begin{tabular}{|c|c|c|c|}
\hline Sample & Control $(\Delta \mathbf{H} \mathbf{~ J / g})$ & Treated $(\Delta \mathbf{H} \mathbf{J} / \mathbf{g})$ & $\%$ Change in $\Delta \mathbf{H}$ \\
\hline Acrylamide & -231.96 & -156.83 & -32.39 \\
\hline 2-Chloroacetamide & -169.44 & -207.55 & 22.49 \\
\hline
\end{tabular}

Table 2: Latent heat of fusion $(\Delta \mathrm{H})$ of control and treated compounds (Acrylamide and 2-Chloroacetamide).

AM. The $\Delta \mathrm{H}$ was changed by $32.39 \%$ in the treated $\mathrm{AM}$ with respect to control. Whereas the control CA showed a $\Delta \mathrm{H}$ of $169.44 \mathrm{~J} / \mathrm{g}$ and it was increased to $207.55 \mathrm{~J} / \mathrm{g}$ in treated CA. The result showed $22.49 \%$ increase in $\Delta \mathrm{H}$ of treated CA as compared to control. It is assumed that biofield may altered the internal energy of the treated compounds (AM and $\mathrm{CA}$ ) which led to significant change in $\Delta \mathrm{H}$ with respect to control samples.

\section{TGA studies}

Thermal stability of the control and treated AM and CA compounds were evaluated using TGA. TGA thermogram of control and treated AM are presented in Figures 7 and 8. The TGA thermogram of control AM showed (Figure 7) one step thermal degradation pattern. The thermal degradation commence at around $148^{\circ} \mathrm{C}$ (onset) and degradation stopped at around $195^{\circ} \mathrm{C}$ (end set). This step showed a major weight loss and the sample lost $58.82 \%$ of its weight. However, DTA thermogram of control AM showed an endothermic peak at $86^{\circ} \mathrm{C}$ which may be associated with the melting temperature of the sample. The thermogram showed another endothermic peak at $174^{\circ} \mathrm{C}$ that may be due to thermal decomposition or breaking of intermolecular hydrogen bonding between AM. Derivative thermogravimetry (DTG) of the control AM exhibited the maximum thermal decomposition temperature $\left(\mathrm{T}_{\max }\right)$ at $164^{\circ} \mathrm{C}$. However, the treated $\mathrm{AM}$ thermogram also showed (Figure 8) single step thermal decomposition pattern. The thermal degradation started at around $135^{\circ} \mathrm{C}$ (onset) and terminated at around $190^{\circ} \mathrm{C}$ (end set). During this step the treated AM showed $68.68 \%$ of weight loss. DTA thermogram of the treated AM showed melting peak at $85^{\circ} \mathrm{C}$ and second endothermic was seen at $176^{\circ} \mathrm{C}$ (thermal decomposition). The DTG thermogram of treated AM showed no change in $\mathrm{T}_{\text {max }}$ value $\left(164^{\circ} \mathrm{C}\right)$ as compared to control. It may be corroborated to no alteration in thermal stability of treated AM with respect to control after biofield treatment. The TGA thermogram of control and treated CA are shown in Figures 9 and 10. The control CA showed occurrence of one step thermal degradation pattern. Thermal degradation commenced at around $120^{\circ} \mathrm{C}$ (onset) and completed at around $190^{\circ} \mathrm{C}$ (end set). During this process the sample showed (Figure 9) major weight loss $(66.09 \%)$ that might be due to thermal decomposition of the CA chain. DTA thermogram of CA showed an endothermic peak at $115^{\circ} \mathrm{C}$; associated with the melting of the sample. Another endothermic event was noticed at $162^{\circ} \mathrm{C}$ that may be due to thermal decomposition. The $\mathrm{T}_{\max }$ of control CA was observed at $150^{\circ} \mathrm{C}$ as shown by the DTG thermogram. TGA thermogram of treated CA showed (Figure 10) one step thermal degradation between $130-210^{\circ} \mathrm{C}$. During this thermal event sample showed rapid thermal degradation and weight loss $(61.16 \%)$. However, the DTA thermogram of treated
CA showed two endothermic peaks at $116^{\circ} \mathrm{C}$ and $176^{\circ} \mathrm{C}$. The former endothermic was due to melting and later peak was attributed to thermal decomposition. The DTG thermogram of treated CA showed increase in $\mathrm{T}_{\max }$ value $\left(167^{\circ} \mathrm{C}\right)$ as compared to control sample $\left(150^{\circ} \mathrm{C}\right)$. This increase in thermal decomposition may be correlated to high thermal stability of the treated CA.

\section{Surface area analysis}

Surface area of AM and CA was investigated using BET method. The surface area result of control and treated compounds (AM and CA) are presented in Table 3. The control AM showed a surface area of $0.42 \mathrm{~m}^{2} / \mathrm{g}$, however, the treated AM showed $0.55 \mathrm{~m}^{2} / \mathrm{g}$. The percentage increase in surface area was $31.6 \%$ in the treated AM

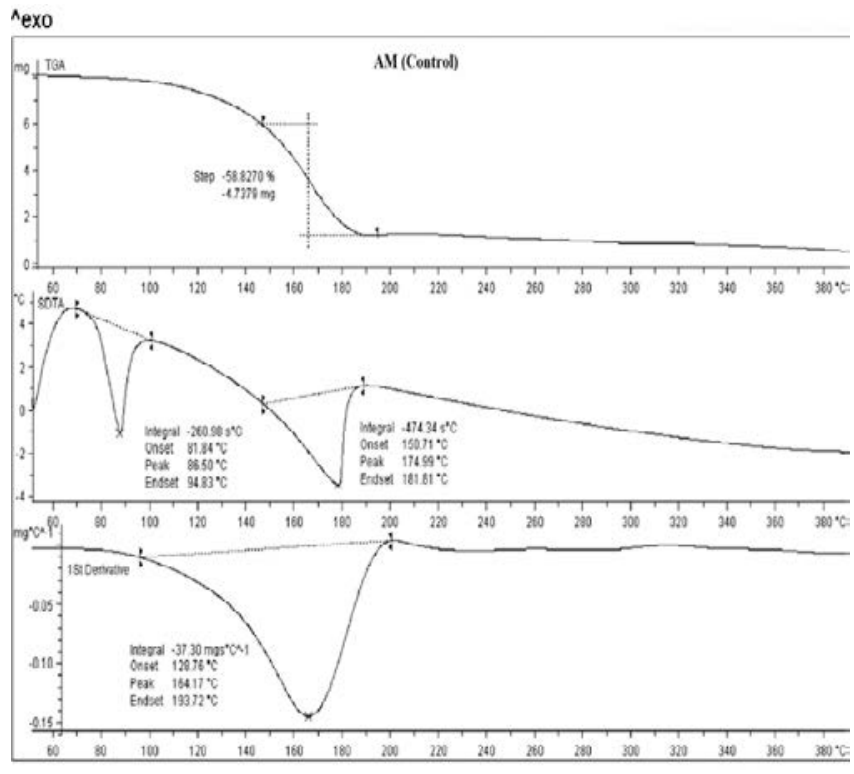

Figure 7: TGA thermogram of control acrylamide (AM).

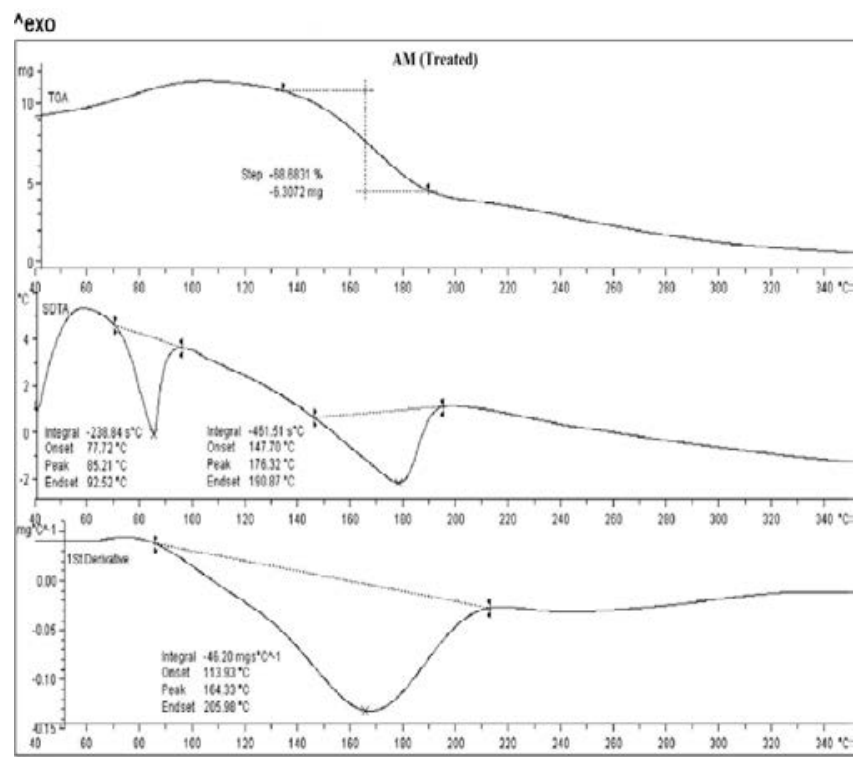

Figure 8: TGA thermogram of treated acrylamide (AM). 
Citation: Mahendra KT, Shrikant P, Rakesh KM, Snehasis J (2015) Characterization of Thermal and Physical properties of Biofield Treated Acrylamide and 2-Chloroacetamide. Organic Chem Curr Res 4: 143. doi:10.4172/2161-0401.1000143

Page 5 of 6

\begin{tabular}{|c|c|c|c|}
\hline Sample & Control $\left(\mathbf{m}^{2} \mathbf{g}\right)$ & Treated $\left(\mathbf{m}^{2} / \mathbf{g}\right)$ & $\%$ Change in surface area \\
\hline Acrylamide & 0.42 & 0.55 & 31.6 \\
\hline 2-Chloroacetamide & 0.65 & 0.45 & -30.9 \\
\hline
\end{tabular}

Table 3: Surface area data of acrylamide (AM) and 2-chloroacetamide (CA).

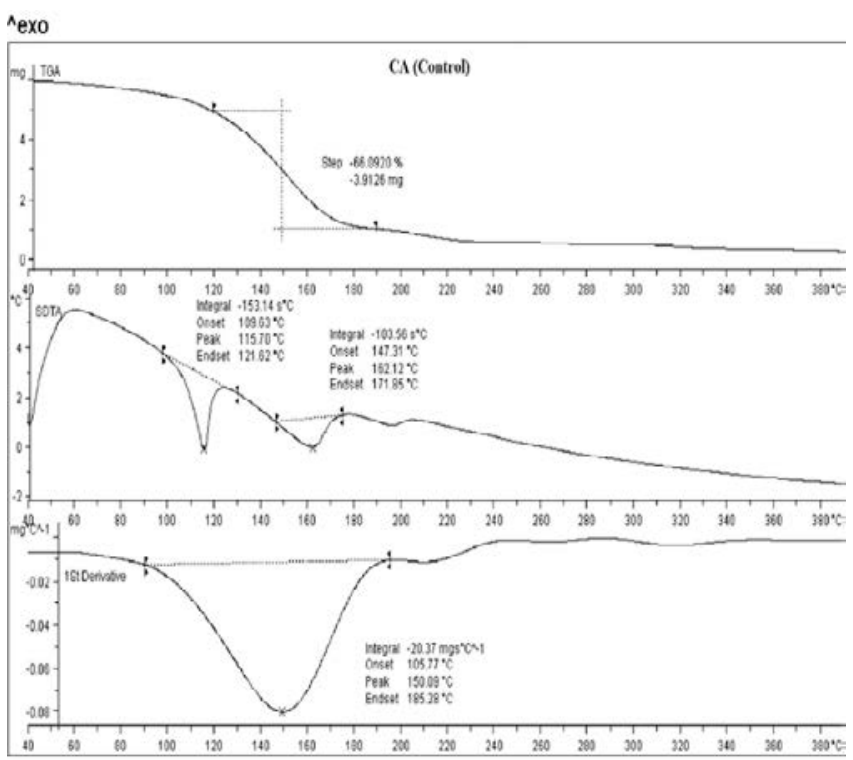

Figure 9: TGA thermogram of control 2-chloroacetamide (CA)

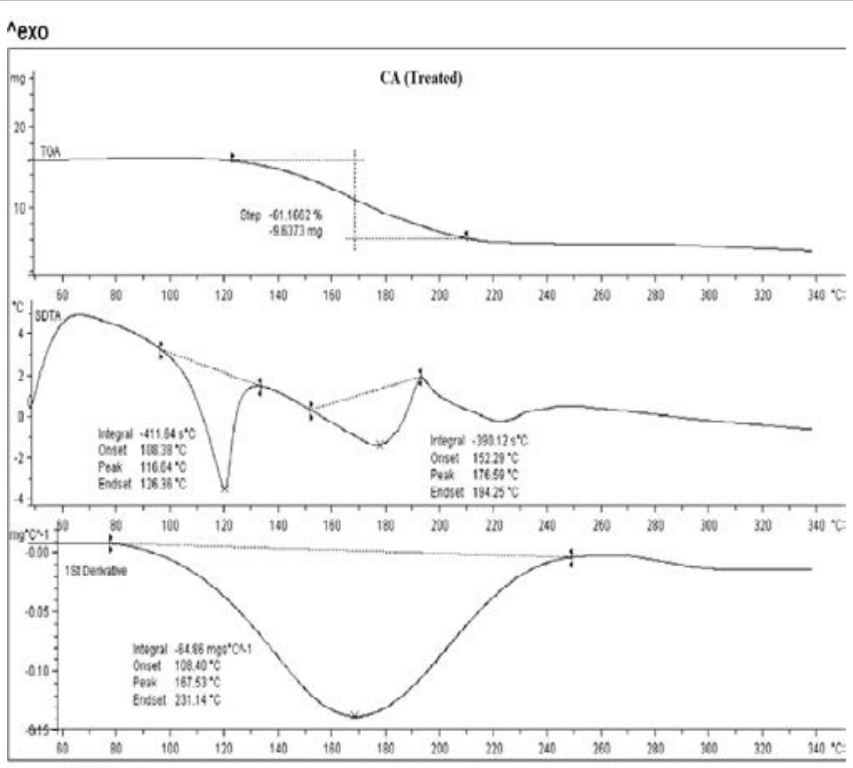

Figure 10: TGA thermogram of treated 2-chloroacetamide (CA).

sample as compared to control. It is hypothesized that energy milling provided by biofield treatment might cause fracturing in particles and thus reduction in particle size. Hence, reduction in particle size causes increase in surface area of the treated AM [36,37]. The control CA showed surface area $0.65 \mathrm{~m}^{2} / \mathrm{g}$; however, it decreased to $0.45 \mathrm{~m}^{2} / \mathrm{g}$ in treated sample. The percentage decrease in surface area was $30.9 \%$ in treated CA as compared to control sample. The biofield energy may increase the particle size that lead to decrease in surface area.

\section{Conclusion}

The present work investigated the influence of biofield treatment on physical and thermal properties of AM and CA. The XRD results showed the decrease in crystallinity of treated AM as compared to control. The crystallite size was also decreased in treated AM with respect to control. Whereas, treated CA showed significant increase in crystallite size as compared to control. DSC showed increase in melting temperature of both treated $\mathrm{AM}$ and $\mathrm{CA}$ with respect to control. Additionally, latent heat of fusion of treated compounds was substantially changed as compared to control. TGA showed enhanced thermal decomposition temperature in CA as compared to control that indicated the higher thermal stability after biofield treatment. However, no change in thermal stability was observed in treated AM with respect to control. Overall, the results indicated that biofield treatment has significant impact in alteration of the physical and thermal properties of $\mathrm{AM}$ and CA.

\section{Acknowledgement}

The authors would like to thank all the laboratory staff of MGV Pharmacy College, Nashik for their assistance during the various instrument characterizations We thank Dr. Cheng Dong of NLSC, institute of physics, and Chinese academy of sciences for permitting us to use Powder $X$ software for analyzing XRD results.

\section{References}

1. Raymond S, Weintraub L (1959) Acrylamide gel as a supporting medium for zone electrophoresis. Science 130: 711.

2. Yang TH (2008) Recent applications of polyacrylamide as biomaterials. Recent Pat Mater Sci 1: 29-40.

3. Bernfeld P, Wan J (1963) Antigens And Enzymes Made Insoluble By Entrapping Them Into Lattices Of Synthetic Polymers. Science 142: 678-679.

4. Abrahám M, Horváth L, Simon M, Szajáni B, Boross L (1985) Characterization and comparison of soluble and immobilized pig muscle aldolases. App Biochem Biotechnol 11: 91-100.

5. Ratner BD, Hoffmann AS, Schoen FJ, Lemons J (1996) Biomaterial Science. Academic Press, New York.

6. Langer R1 (1998) Drug delivery and targeting. Nature 392: 5-10.

7. Davis BK (1972) Control of diabetes with polyacrylamide implants containing insulin. Experientia 28: 348.

8. Hussain MD, Rogers JA, Mehvar R, Vudathala GK (1999) Preparation and release of ibuprofen from polyacrylamide gels. Drug Dev Ind Pharm 25: 265271

9. Sairam M, Babu VR, Vijaya B, Naidu K, Aminabhavi TM, et al. (2006 Encapsulation efficiency and controlled release characteristics of crosslinked polyacrylamide particles. Int J Pharm 320: 131-136.

10. Soppimath KS, Kulkarni AR, Aminabhavi TM (2001) Chemically modified polyacrylamide-g-guar gum-based crosslinked anionic microgels as $\mathrm{pH}$ sensitive drug delivery systems: preparation and characterization. J Control Release 75: 331-345

11. Murakami Y, Maeda M (2005) DNA-responsive hydrogels that can shrink or swell. Biomacromolecules 6: 2927-2929.

12. Christensen LH, Breiting VB, Aasted A, Jørgensen A, Kebuladze I, et al. (2003) Long-term effects of polyacrylamide hydrogel on human breast tissue. Plast Reconstr Surg 111: 1883-1890.

13. Zheng J, Li R, Zhu J, Zhang J, He J, et al. (2012) Degradation of the chloroacetamide herbicide butachlor by Catellibacterium caeni sp. nov DCA1T. Int Biodeter Biodegr 73: 16-22.

14. Sonmez HB, Bicak N (2002) Quaternization of poly (4-vinyl pyridine) beads with 2-chloroacetamide for selective mercury extraction. React Funct Polym 51: $55-60$

15. Allen Jr HC (1952) The pure quadrupole spectra of solid chloroacetic acids and substituted chloroacetic acid. J Am Chem Soc 74: 6074-6076.

16. Allen Jr HC (1953) Pure quadruple spectra of molecular crystals. J Phys Chem 57: $501-504$ 
Citation: Mahendra KT, Shrikant P, Rakesh KM, Snehasis J (2015) Characterization of Thermal and Physical properties of Biofield Treated Acrylamide and 2-Chloroacetamide. Organic Chem Curr Res 4: 143. doi:10.4172/2161-0401.1000143

17. Trivedi MK, Patil S, Tallapragada RM (2013) Effect of biofield treatment on the physical and thermal characteristics of vanadium pentoxide powders. $J$ Material Sci Eng S11: 001.

18. Trivedi MK, Patil S, Tallapragada RM (2013) Effect of biofield treatment on the physical and thermal characteristics of silicon, tin and lead powders. J Material Sci Eng 2: 125

19. Trivedi MK, Patil S, Tallapragada RMR (2015) Effect of biofield treatment on the physical and thermal characteristics of aluminium powders. Ind Eng Manag 4: 151

20. Trivedi MK, Patil S, Tallapragada RM (2014) Atomic, crystalline and powder characteristics of treated zirconia and silica powders. J Material Sci Eng 3: 144

21. Korotkov K (2002) Human Energy Field: study with GDV bioelectrography. NY Backbone publishing.

22. Myers R (2003) The basics of chemistry. Greenwood Press, Westport, Connecticut.

23. Movaffaghi Z, Farsi M (2009) Biofield therapies: biophysical basis and biological regulations? Complement Ther Clin Pract 15: 35-37.

24. Shinde V, Sances F, Patil S, Spence A (2012) Impact of biofield treatment on growth and yield of lettuce and tomato. Aust J Basic \& Appl Sci 6: 100-105.

25. Sances F, Flora E, Patil S, Spence A, Shinde V, et al. (2013) Impact of biofield treatment on ginseng and organic blueberry yield. Agrivita J Agric Sci 35: 2229.

26. Lenssen AW (2013) Biofield and fungicide seed treatment influences on soybean productivity, seed quality and weed community. Agricultural Journal 8: 138-143.

27. Altekar N, Nayak G (2015) Effect of biofield treatment on plant growth and adaptation. J Environ Health Sci 1: 1-9.
28. Trivedi MK, Patil S (2008) Impact of an external energy on Staphylococcus epidermis [ATCC -13518] in relation to antibiotic susceptibility and biochemical reactions - An experimental study. J Accord Integr Med 4: 230-235.

29. Trivedi MK, Patil S (2008) Impact of an external energy on Yersinia enterocolitica [ATCC -23715$]$ in relation to antibiotic susceptibility and biochemical reactions: An experimental study. Internet J Alternative Med 6.

30. Trivedi MK, Bhardwaj Y, Patil S, Shettigar H, Bulbule A, et al. (2009) Impact of an external energy on Enterococcus faecalis [ATCC - 51299] in relation to antibiotic susceptibility and biochemical reactions - An experimental study. $J$ Accord Integr Med 5: 119-130.

31. Patil SA, Nayak GB, Barve SS, Tembe RP, Khan RR (2012) Impact of biofield treatment on growth and anatomical characteristics of Pogostemon cablin (Benth.). Biotechnology 11: 154-162.

32. Rashidi AM, Amadeh A (2009) The effect of saccharin addition and bath temperature on the grain size of nanocrystalline nickel coatings. Surf Coat Technol 204: 353-358.

33. Katayama M (1956) The crystal structure of an unstable form of chloroacetamide Acta Crystallogr 9: 986-991.

34. Gusain D, Srivastava V, Singh VK, Sharma YC (2014) Crystallite size and phase transition demeanor of ceramic steel. Mater Chem Phys 146: 320-326.

35. Szabo L, Cik G, Lensy J (1996) Thermal stability increase of doped poly (hexadecylthiophene) by ?-radiation. Synt Met 78: 149-153.

36. Mennucci B, Martinez JM (2005) How to model solvation of peptides? Insights from a quantum-mechanical and molecular dynamics study of $\mathrm{N}$-methylacetamide. I. Geometries, infrared, and ultraviolet spectra in water. J Phys Chem B 109: 9818-9829.

37. Bendz D, Tüchsen PL, Christensen TH (2007) The dissolution kinetics of majo elements in municipal solid waste incineration bottom ash particles. J Contam Hydrol 94: 178-194.
Citation: Mahendra KT, Shrikant P, Rakesh KM, Snehasis J (2015) Characterization of Thermal and Physical properties of Biofield Treated Acrylamide and 2-Chloroacetamide. Organic Chem Curr Res 4: 143. doi:10.4172/2161-0401.1000143
Submit your next manuscript and get advantages of OMICS Group submissions

Unique features:

- User friendly/feasible website-translation of your paper to 50 world's leading languages

- Audio Version of published paper

Digital articles to share and explore

Special features:

400 Open Access Journals

35,000 editorial team

21 days rapid review process

Quality and quick editorial, review and publication processing

- Indexing at PubMed (partial), Scopus, DOAJ, EBSCO, Index Copernicus and Google Scholar etc

- Sharing Option: Social Networking Enabled

- Authors, Reviewers and Editors rewarded with online Scientific Credits

- Better discount for your subsequent articles

Submit your manuscripts as E- mail: editor.organicchemistry@omicsonline.org 